\title{
Airflow Influence on Smoke Detectors Arrangement in Corridors
}

\author{
Radoje Jevtić ${ }^{1)}$
}

\begin{abstract}
Fire detectors arrangement presents a very important task in fire protection. This task was defined by valid standards. Although the standards should be equal or at least similar, there are situations where different standards demand different rules about detectors arrangement. One of those specific situations is the corridor case. Corridor definition is different from standard to standard, so as smoke detectors arrangement in corridors. This is especially interesting with the presence of some disturbing factors, such as airflow. This paper has been written to show smoke detectors arrangement in corridors according to the five leading standards in the field of fire protection, potential airflow influence on smoke detectors reaction in dependence of different detectors arrangement and different fire location, such as advantages of simulation software usage.
\end{abstract}

Key words: fire, detector, standard, airflow, arrangement.

\section{Introduction}

$\mathrm{F}$ IRE detectors arrangement in an object presents a very important task in fire protection and alarming at early stage of fire. The main aim of those measurements is to save human lives and material properties. Fire detectors are different and can be classified in different ways, related to different criteria (smoke detectors, heat detectors, flame detectors, gas detectors, etc.) Those criteria are related to combustion product types, effective zone of detector, detector's activation mode, etc.

Fire detectors arrangement was defined by standards. There are several valid standards that deal with these problems: BS (British Standard), EN 54 (European norms), NFPA (National Fire Protection Association), СП 5.13130 (Свод Правил), VDE 088-2 (Verband der Elektrotechnik - origionally-Association of German Electrical Enginners, now - Association for Electrical, Electronic \&Information Technologies) and other.

The needed number of fire detectors in a room is, generally, defined as quotient of the room's surface and supervised surface of particular detector. In addition, there are lot of other factors that must be considered, such as position of the walls, roofs shape, presence of different barriers, presence of different gaps, airflows, humidity and many others. It is very important that detectors are visible and easily accessible for testing and repairing purposes.

Related to those standards, smoke detectors as a type of fire detectors must "cover" a complete surface of the monitored area. The potential cases for smoke detectors, related to the monitored surface covering, are presented in Fig.1.

Smoke detectors arrangement shown in Fig.1 with number 1 presents smoke detectors arrangement with uncovered areas. It means that there is a possibility for smoke to be undetected or detected lately. Smoke detectors arrangement shown in Fig.1 with number 2 presents smoke detectors arrangement with so called "redundancy". The complete number of smoke detectors was such that there exist areas with multiple covering. Smoke detectors arrangement shown in Fig.1 with number 3 presents an optimal smoke detectors arrangement with optimal number of smoke detectors and optimal arrangement [1].



Figure 1. The potential cases for smoke detectors related to the monitored surface (Figure source: Blagojević,M., Jevtić,R. and Ristić,D.: Comparative analysis of rules for smoke detectors arrangement in corridors, Facta Universitatis, Working and Environmental Protection, Vol 14, $\mathrm{N}^{\circ} 2$, pp. 149158, ISSN 0354-804X, Niš, Serbia, 2017.)

The smoke detectors arrangement was defined by different standards for general cases and for special cases. One of the most interesting special cases is the corridor case. The reason for that lies in the fact that the corridor definitions for the different standards are quite different.

"European standard EN 54-14 generally permits the use of these detectors to a height of $11 \mathrm{~m}$, with a coverage radius of 7.5 $m$. In practice, an area of coverage greater than $80 \mathrm{~m}^{2}$ is rarely used, but this radius in essence, gives a coverage area of individual detectors even $112 \mathrm{~m}^{2}$. So, smoke detectors arrangement for this case should be realized as for general cases (in this paper, the distance between smoke detectors was $15 \mathrm{~m}$ ) [2].

According to the VDE 0833-2 standard, there are strict references: "In corridors and ceiling bays up to $3 \mathrm{~m}$ width, detectors may be spaced as follows: Heat detectors up to $10 \mathrm{~m}$ apart from each other. Smoke detectors up to $15 \mathrm{~m}$ apart from each other" [3].

\footnotetext{
1) Electrotechnical School "Nikola Tesla", 18000 Niš, SERBIA

Correspondence to: Radoje Jevtić , e-mail: milan.jvtc@gmail.com
} 
Current standard in Russia is Свод правил СП 5.13130. According to this standard: „При установке точечных дымовых пожарных извещателей в помещениях шириной менее 3 м или под фальшполом или над фальшпотолком и $в$ других пространствах высотой менее 1,7 м расстояния между извешателями, указанные в таблице 13.3, допускается увеличивать в 1,5 раза". According to noted, in the rooms with wide of $3 \mathrm{~m}$ and less, also in the double ceiling or in the rooms with height less than $1.7 \mathrm{~m}$, nominal detectors surface can be increased for 1.5 times. So, maximal distance between smoke detectors in this case, for rooms with the height which is less than $3.5 \mathrm{~m}$, is $9 \times 1.5=13.5 \mathrm{~m}$. That means the rules for smoke detectors arrangement from noted table 13.3 from the Russian standard are presented in Table 1 [4].

Table 1. Smoke detectors arrangement rules

\begin{tabular}{|c|c|c|c||}
\hline \multirow{2}{*}{$\begin{array}{c}\text { Room } \\
\text { height } \\
{[\mathrm{m}]}\end{array}$} & $\begin{array}{c}\text { Detector supervised area } \\
{\left[\mathrm{m}^{2}\right]}\end{array}$ & \multicolumn{2}{|c|}{$\begin{array}{c}\text { Maximal range } \\
{[\mathrm{m}]}\end{array}$} \\
\cline { 3 - 4 } & between detectors & $\begin{array}{c}\text { detector from the } \\
\text { wall }\end{array}$ \\
\hline \hline up to 3.5 & up to 85 & 9.0 & 4.5 \\
\hline $3.5-6.0$ & up to 70 & 8.5 & 4.0 \\
\hline $6.0-10.0$ & up to 65 & 8.0 & 4.0 \\
\hline $10.5-12.0$ & up to 55 & 7.5 & 3.5 \\
\hline
\end{tabular}

NFPA 72 standard presents one of the most complex and most detailed standards related to corridors. According to this standard, the corridor case is defined as follows: " $A$ corridor 10 feet $(3.0 \mathrm{~m})$ wide and up to 82 feet $(25.0 \mathrm{~m})$ long can be covered with two 30 feet $(9.1 \mathrm{~m})$ spot type detectors. if a detector is assigned a coverage area of 10 feet $(3.1 \mathrm{~m})$ by 41 feet $(12.5 \mathrm{~m})$, permitted under a 30 feet $(9.1 \mathrm{~m})$ spacing, and two such rectangular areas are stacked end-to-end, such as might be encountered in a corridor, there will be a distance of 42 feet $(12.8 \mathrm{~m})$ between adjacent detectors. The distance of 42 feet $(12.8 \mathrm{~m})$ between adjacent detectors in a corridor is consistent with the 30 feet $(9.1 \mathrm{~m})$ spacing for the detectors. For corridors of approximately 15 feet $(4.6 \mathrm{~m})$ in width and for fires of approximately $100 \mathrm{~kW}$ or greater, modelling has demonstrated that the performance of smoke detectors in corridors with beams has been shown to be comparable to spot smoke detector spacing on an unconfined smooth ceiling surface. In the narrowest of corridors, smoke detectors can be located as far apart as approximately 40 feet $(12.2 \mathrm{~m})$, regardless of the beams or joists at the ceiling" [5].

According to the British standard BS 5839-1, in the corridors where the width of the corridor is less than $5 \mathrm{~m}$, horizontal distance between detectors can be increased for half of difference between $5 \mathrm{~m}$ and corridor's width. That means, if the corridor width was marked as $l$, the covering radius can be presented as:

- for heat detectors, $(5 \mathrm{~m}-l) / 2+5.3[\mathrm{~m}]$,

- for smoke detectors, $(5 \mathrm{~m}-l) / 2+7.5[\mathrm{~m}]$.

Related to the formulae, it is clear if corridor has a width of $3 \mathrm{~m}$, the covering radius will be increased for $1 \mathrm{~m}$. Because of that, the distance between smoke detectors will be $2 \times 8.5 \mathrm{~m}=$ $17 \mathrm{~m}$.

Generally, it is clear that airflow has direct influence on smoke detectors efficiency. Because of that fact, it is very important to pay attention for design in objects with central systems of air conditioning and ventilation. The minimum distance for smoke detector from ventilation gap should be at least $0.5 \mathrm{~m}$. For ventilation realized through perforated ceiling, all of the perforation gaps must be closed in radius from $0.5 \mathrm{~m}$. Smoke detectors can be installed in area where airflow is not bigger than $5 \mathrm{~m} / \mathrm{s}$, except in case that properties of smoke detector enable the smoke detector appliance for airflows bigger than $5 \mathrm{~m} / \mathrm{s}$ [6].

However, what if in the corridor without airflow and smoke detectors arrangement according to valid standards, for some reason (broken glass, open door, etc.), airflow occurs anyway? How would the detectors react and how long would it take the detectors to react?

This paper was written to show a comparative analysis of smoke detectors reaction, arranged according to the valid standards, with and without airflow influence realized by a computer simulation.

\section{Simulation model}

Computer simulation was realized in FDS software (version 6.6). This software is intended for simulation of fire and smoke occurrences and their spreading in object. This one and similar software present very important simulation tool for solving different tasks in the field of fire protection and fire systems design.

As a simulation model for this paper, an object with dimensions $70 \mathrm{~m}$ x $25 \mathrm{~m}$ x $3.35 \mathrm{~m}$ was chosen. Smoke detectors were arranged according to the rules that all of five noted standards demand. There were three different cases for smoke detectors testing, each for different burner's position. The burner itself was presented as fire source with dimensions $0.7 \mathrm{~m} \times 0.7 \mathrm{~m}$ and HRR (Heat Release Rate) from $1,5 \mathrm{~kW} / \mathrm{m}^{2}$. The 2D simulation model of the object with its dimensions, airflow direction and the burner's positions in object (marked as 1,2 and 3) are presented in Figure 2. Simulation models of the object with smoke detectors arrangement according to the EN-54, VDE 0833-2, НПБ 88, NFPA 72 and BS 5839-1 standards are presented in Figures from 3 to 6 [7].



Figure 2. Simulation model of the object with marked burners positions, airflow direction and dimensions

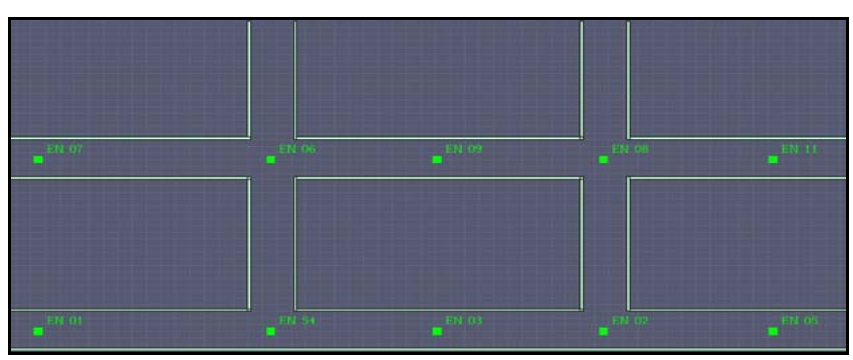

Figure 3. Smoke detectors arrangement related to EN-54 and VDE standard 


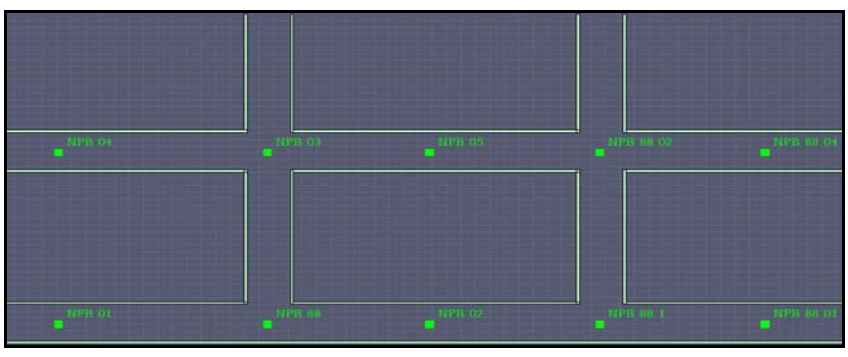

Figure 4. Smoke detectors arrangement related to CП 5.13130 standard

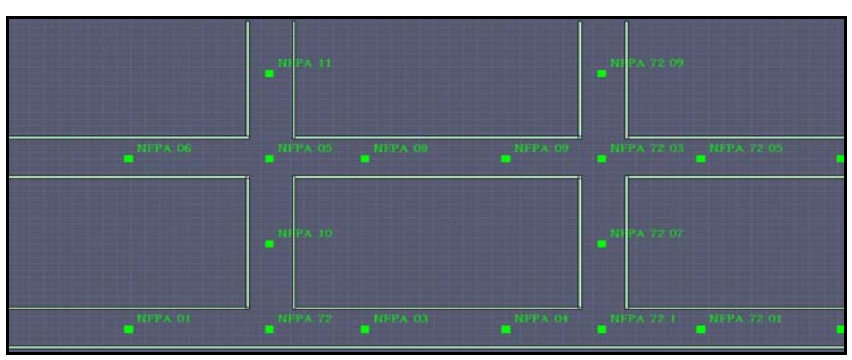

Figure 5. Smoke detectors arrangement related to NFPA 72 standard

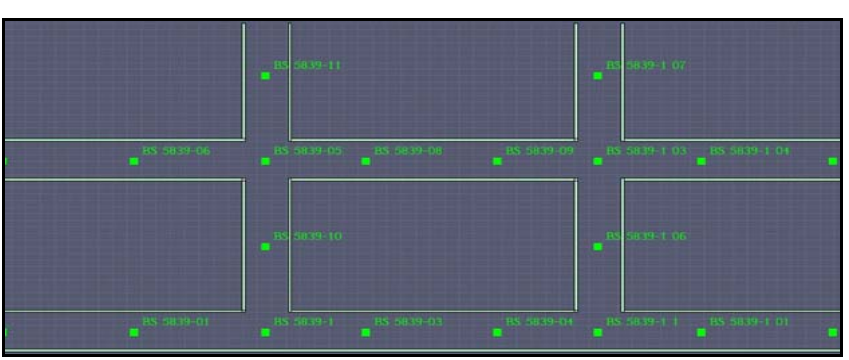

Figure 6. Smoke detectors arrangement related to BS 5839 standard

\section{Simulation results}

The computer which was used for simulation in this paper was Laptop Dell Vostro 14 5481, equipped with Intel Core i58265U at 1.6 GHz; 8 GB DDR4 (2666 MHz, Hundai); graphic processor Intel HD Graphichs $620+$ Nvidia GeForce MX130. For this and similar computer simulations, the reference is to use as much as powerful computer (in hardware sense).

The complete simulation time was set to 300 seconds. Simulation moments for the first and second burner's positions, for airflows of $10 \mathrm{~m} / \mathrm{s}$ and $3 \mathrm{~m} / \mathrm{s}$ are presented in Figures 7 and 8 . The complete simulation results without airflow and with airflow for all three burner's positions are presented in Figures from 9 to 12. An example of the response time of the closest detectors related to the third burner position and airflow of $5 \mathrm{~m} / \mathrm{s}$, for detectors arrangement related to the CП 5.13130 and BS 5839 standards is presented in Fig.13.

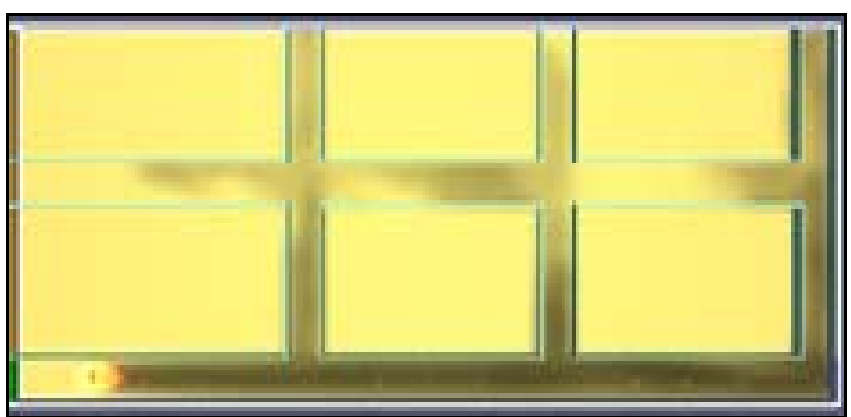

Figure 7. Simulation moment for the first burner position and airflow of 10 $\mathrm{m} / \mathrm{s}$

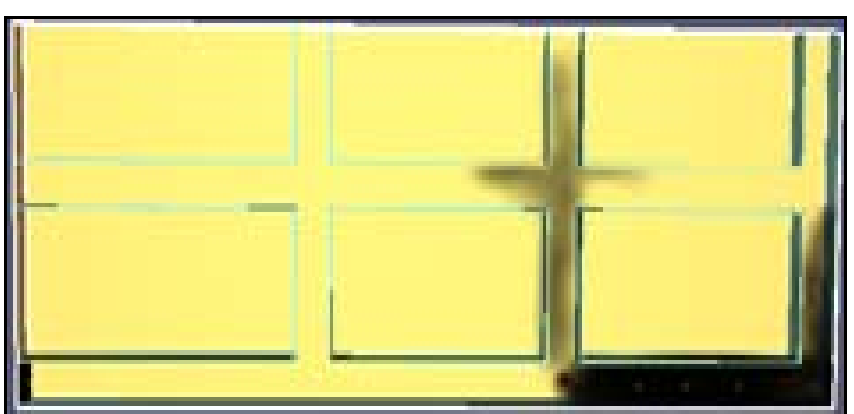

Figure 8. Simulation moment for the second burner position and airflow of 3 $\mathrm{m} / \mathrm{s}$

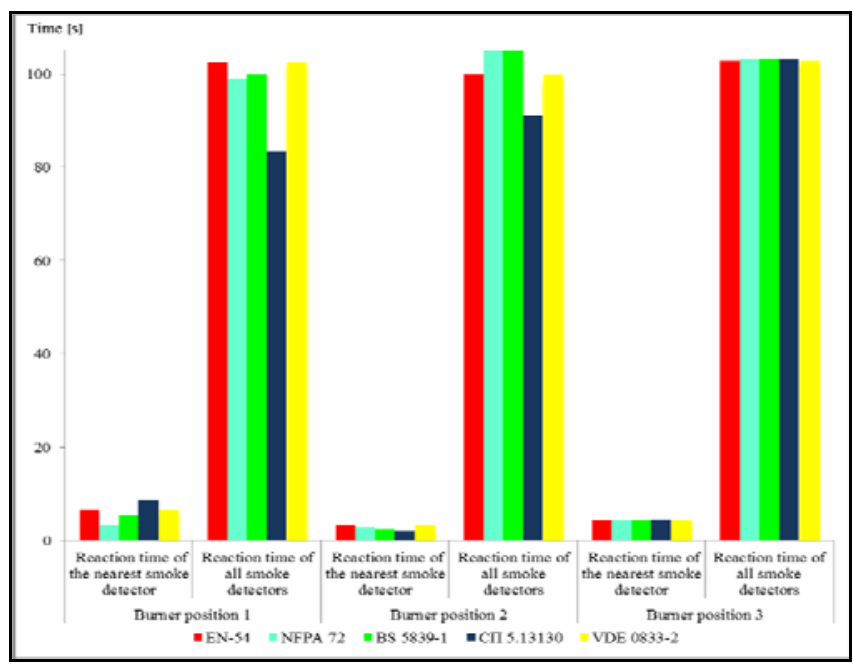

Figure 9. Reaction times for the nearest and for all smoke detectors related to valid standards, for every of three burner's positions, without airflow

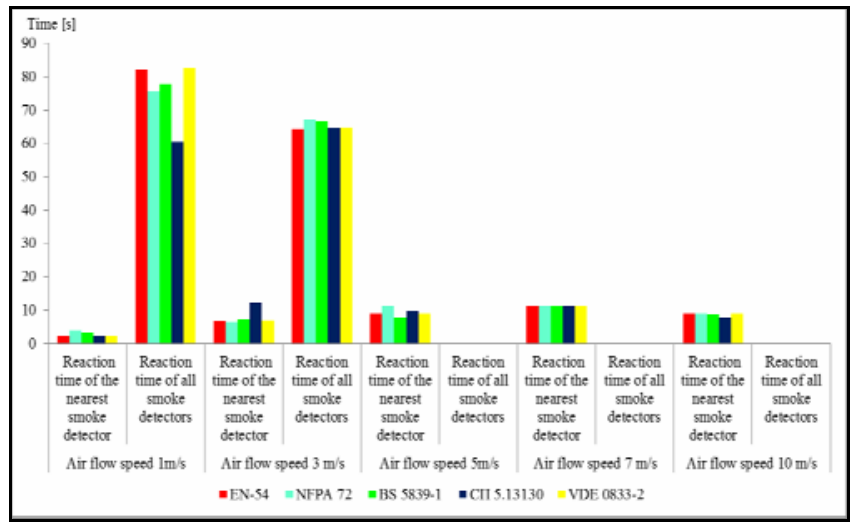

Figure 10. Reaction times for the nearest and for all smoke detectors related to valid standards, for the first burner position, for airflows of $1 \mathrm{~m} / \mathrm{s}, 3 \mathrm{~m} / \mathrm{s}, 5$ $\mathrm{m} / \mathrm{s}, 7 \mathrm{~m} / \mathrm{s}$ and $10 \mathrm{~m} / \mathrm{s}$

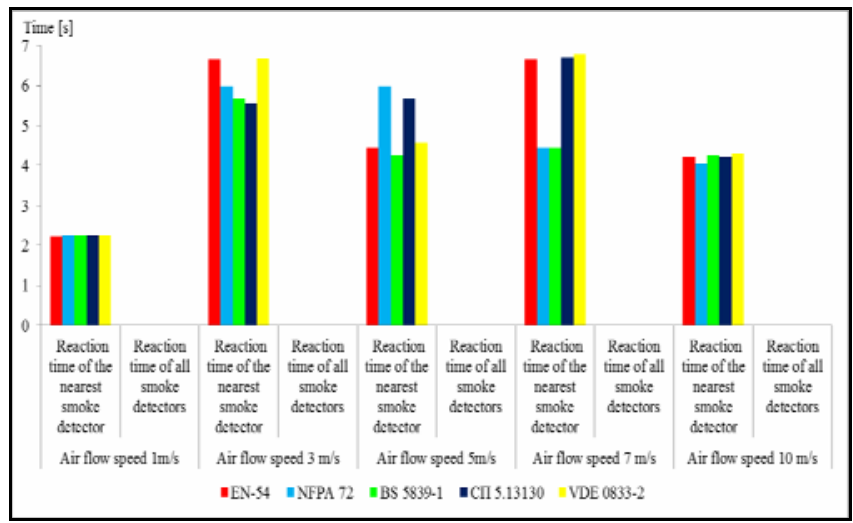

Figure 11. Reaction times for the nearest and for all smoke detectors related to valid standards, for the second burner position, for airflows of $1 \mathrm{~m} / \mathrm{s}, 3 \mathrm{~m} / \mathrm{s}$, $5 \mathrm{~m} / \mathrm{s}, 7 \mathrm{~m} / \mathrm{s}$ and $10 \mathrm{~m} / \mathrm{s}$ 


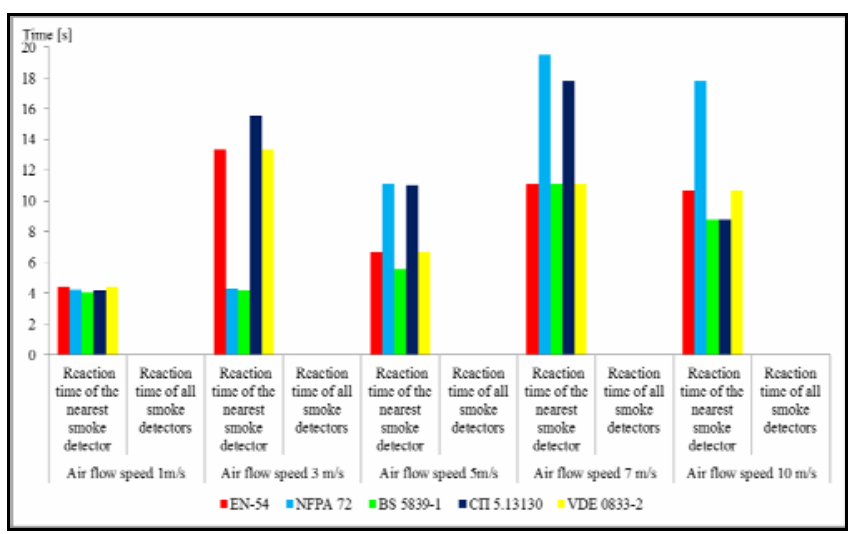

Figure 12. Reaction times for the nearest and for all smoke detectors related to valid standards, for the third burner position, for airflows of $1 \mathrm{~m} / \mathrm{s}, 3 \mathrm{~m} / \mathrm{s}, 5$ $\mathrm{m} / \mathrm{s}, 7 \mathrm{~m} / \mathrm{s}$ and $10 \mathrm{~m} / \mathrm{s}$

\section{CП 5.131302}

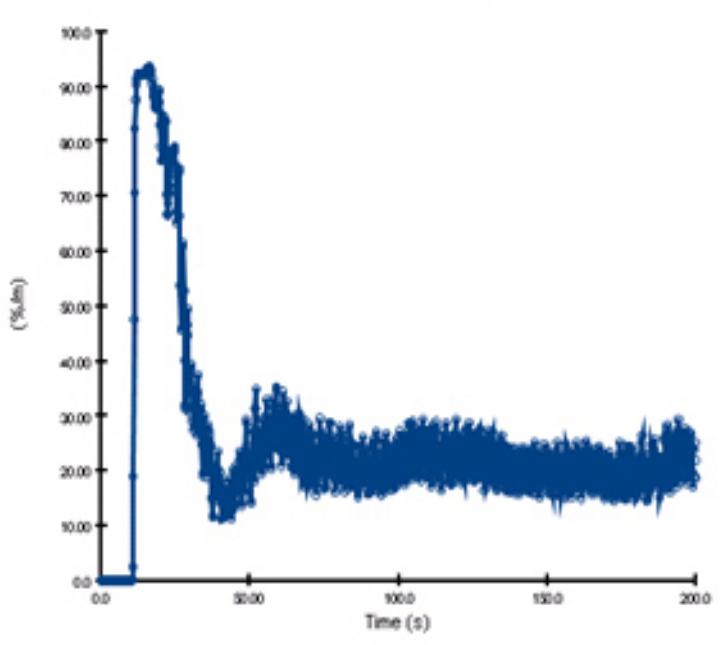

a)

BS 582-1 01

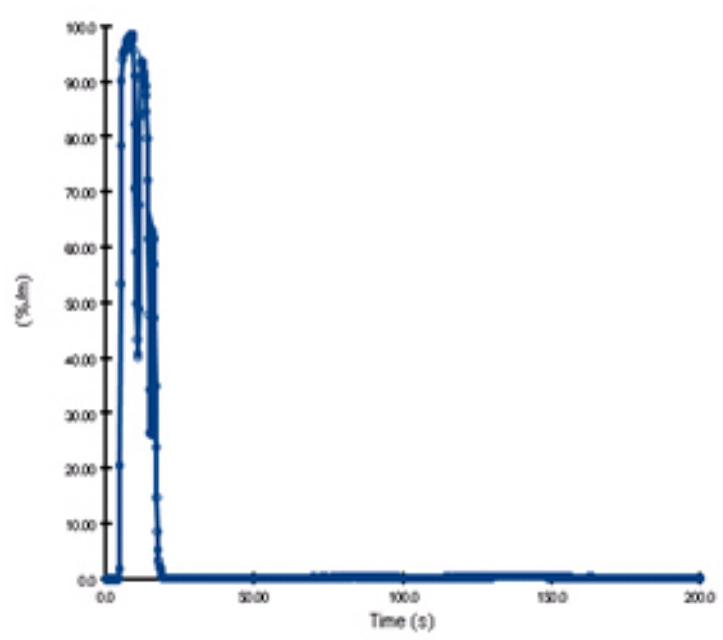

Figure 13. An example of the response time of the closest detectors related to the third burner position and airflow of $5 \mathrm{~m} / \mathrm{s}$, for detectors arrangement related to the CП 5.13130 and BS 5839 standards

\section{Results analysis}

According to Fig.9, it can be concluded that for every of three burner positions and for every detectors' arrangement related to the noted standards, smoke detectors reacted. The nearest smoke detectors, in dependence of smoke detectors arrangement, reacted in duration below 20 seconds. The reaction time of all detectors was from 80 to 105 seconds, depending from the smoke detectors arrangement and burner`s position. For the first and the second burner's position, the fastest reaction time for all detectors was in case when detectors were arranged according to the CП 5.13130 standard, while for the third burner`s position, reaction times for all detectors according to the noted standards were almost equal.

Results for the first burner position and airflows from $1 \mathrm{~m} / \mathrm{s}$ to $10 \mathrm{~m} / \mathrm{s}$ (Fig. 10) showed that for airflows of $1 \mathrm{~m} / \mathrm{s}$ and $3 \mathrm{~m} / \mathrm{s}$ existed reaction times for all detectors, while for airflows of 5 $\mathrm{m} / \mathrm{s}, 7 \mathrm{~m} / \mathrm{s}$ and $10 \mathrm{~m} / \mathrm{s}$ there was no reaction of all installed detectors. It is important to note that the closest detectors in this case (for burner position marked as 1 in Fig.2) are not the same as the closest detectors in other two cases (for burner positions marked as 2 and 3 in Fig.2).

Results for the second burner position and airflows from 1 $\mathrm{m} / \mathrm{s}$ to $10 \mathrm{~m} / \mathrm{s}$ (Fig. 11 ) showed that for all simulated airflows there was no reaction of all installed detectors. The reaction times for the closest smoke detectors were different for different airflows.

Results for the third burner position and airflows from 1 $\mathrm{m} / \mathrm{s}$ to $10 \mathrm{~m} / \mathrm{s}$ (Fig.12) showed that for all simulated airflows there was no reaction of all installed detectors. The reaction times for the closest smoke detectors were different for different airflows, as in the previous cases.

No matter to smoke detectors arrangement, simulation results showed that, in any case, some of installed smoke detectors (one or more but not all) reacted.

Realized simulation results showed that in the presence of airflow, detectors reaction would be different from the reaction without airflow presence. What is important is the fact that some detectors will always react and that reaction will not depend on whether or not a detector was the closest to the burner's position.

\section{Conclusion}

Comparative analyses of distribution and arrangement of smoke detectors with and without airflow presence, related to five lead world standards, were done in this paper. Noted rules were applied in rooms with regular shapes, flat ceiling and no specific architectural or construction characteristics. No matter for these, let say almost "ideal" rooms, different standards for the same problem showed different solutions.

The first part of the paper that concerned the comparative results without airflow presence (results presented in Fig.9) showed different reaction times for different standards. No matter for small differences, all noted standards are completely satisfactory for most applications in practice, which was one of purposes of this paper. The reaction time for every smoke detector will depend from its distance related to the fire and smoke source (burner).

The second part of paper that concerned the comparative results with airflow presence (results presented in Figures 1012) also showed different results. These results were largely theoretical, but it is not excluded that airflow in corridors may occur, in situations such as opened window, opened door, broken glass, wind strikes, broken ventilation part or similar. For higher speeds of airflow, many smoke detectors will not react. This may cause identification problems in algorithms used for alarm decision making.

One of the most important purposes of this paper was the recommendation for simulation software usage. The appliance 
of simulation software in fire protection presents very important, safe, cheap and effective way of checking fire protection rules and regulations. In this case, the significance of fire simulation software appliance is in the fact that reaction times of smoke detectors for different arrangements can be calculated and compared. It is known that several valid standards in fire protection exist; it is the designers' decision which one to apply and how to realize fire protection rules and laws from case to case. Fire simulation software presents a great help in that sense and opens many new possibilities in fire protection.

\section{References}

[1] BLAGOJEVIĆ,Đ.M.: Alarm systems, Faculty of Occupational Safety in Niš, ISBN 978-86-6093-025-7, Niš, 2015, pp.206, 224.

[2] BLAGOJEVIĆ,M., JEVTIĆ,R., RISTIĆ,D.: Comparative analysis of rules for fire detectors arrangement and distributions in five standards, ОСМА НАУЧНА КОНФЕРЕНЦИЯ С МЕЖДУНАРОДНО УЧАСТИЕ „ГРАЖДАНСКАТА БЕЗОПАСНОСТ 2017“, Sofia,
Bulgaria, 6-7. 04.2017.

[3] DIN VDE 0833-2: Alarm systems for fi re, intrusion and hold up, Requirements for fi re alarm systems, 2009.

[4] http://docs.cntd.ru/document/1200071148: СП 5.13130.2009 Системы противопожарной защиты. Установки пожарной сигнализации и пожаротушения автоматические. Нормы и правила проектирования (с Изменением N 1)

[5] NFPA 72: National Fire Alarm Code, 2007 Edition, NFPA, pp.135, $136,158-161$.

[6] BLAGOJEVIĆ,Đ.M.: Fire protection systems designing, AGM Book, Belgrade, ISBN 978-86-86363-89-3, 2018, pp.114, 81.

[7] MCGRATTAN,K., MCDERMOTT,R., HOSTIKA,S., FLOYD,J., VENELLA,M.: Fire Dynamics Simulator User's Guide, National Institute for Standard and Technology, 2019, pp. 3, 119-125, 199-204, 234, 264, 309-324, 334.

\section{Uticaj vazdušnog strujanja na raspored detektora dima u hodnicima}

\begin{abstract}
Raspored detektora dima predstavlja veoma važan zadatak kada je u pitanju zaštita od požara. Ovaj zadatak je definisan važećim standardima. Iako bi standardi trebalo da budu isti ili bar slični, postoje situacije gde različiti standardi zahtevaju različita pravila vezana za raspored detektora. Jedna od tih karakterističnih situacija je slučaj hodnika. Definicija hodnika se razlikuje od standarda do standarda, pa tako i raspored detektora dima u hodnicima. Ovo je posebno interesantno u prisustvu nekih ometajućih faktora, kao što je vazdušno strujanje. Ovaj rad je napisan da prikaže raspored detektora dima u hodnicima po pet vodećih standarda iz oblasti zaštite od požara, mogući uticaj vazdušnog strujanja na reakciju detektora u zavisnosti od različitog rasporeda detektora i različitog mesta požara, kao i prednosti upotrebe simulacionog softvera.
\end{abstract}

Ključne reči: požar, detektor, standard, vazdušno strujanje, raspored. 